\title{
Enunciação e cidadania: o replanejamento didático na busca pelas culturas negadas e silenciadas em sala de aula
}

\author{
Enunciation and citizen: the didactic replanning in search of denied and silenced \\ cultures in the classroom
}

\section{Giovane Fernandes Oliveira}

Universidade Federal do Rio Grande do Sul - UFRGS - Porto Alegre - Rio Grande do Sul - Brasil

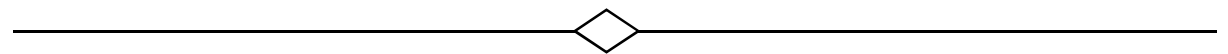

Resumo: Este artigo tem dois objetivos: 1) apresentar um relato de experiência de estágio de docência em Língua Portuguesa e Literatura, realizado numa turma de $7^{\circ}$ ํㅡㄴ ano do Ensino Fundamental de uma escola pública do município de Canoas, na região metropolitana de Porto Alegre (RS); 2) refletir sobre o replanejamento didático em Língua Portuguesa e Literatura a partir das demandas emergentes da turma em questão, demandas estas relacionadas a posturas preconceituosas demonstradas pelos alunos uns em relação aos outros. A partir de uma reflexão conduzida por referenciais teóricos advindos da Linguística e da Educação - a teoria enunciativa de Émile Benveniste, a perspectiva de educação linguística de Simões et al. (2012) e as teorias pós-críticas de currículo e planejamento representadas por Santomé (1995), Corazza (1997) e T. T. Silva (2001) -, chega-se a duas conclusões. Primeira conclusão: é imprescindível inserir, no planejamento didático, as culturas negadas e silenciadas no currículo escolar, a fim de desenvolver junto aos alunos os letramentos críticos e protagonistas (ROJO, 2014), formando-os para o exercício da cidadania e o respeito à diversidade. Segunda conclusão: um planejamento didático pautado numa concepção enunciativa de linguagem e numa perspectiva de educação linguística comprometida com o acesso dos alunos às culturas de escrita contribui para o aprimoramento de suas competências e habilidades relacionadas à leitura e à produção de textos como práticas sociais de uso da língua.

Palavras-chave: Língua Portuguesa e Literatura. Educação Linguística. Enunciação. Replanejamento didático. Letramento crítico.

\begin{abstract}
This article has two objectives: 1) to present an experience report of a teacher training internship program in Portuguese Language and Literature, carried out in a 7th grade class at a public school in the municipality of Canoas, in the metropolitan area of Porto Alegre (RS); 2) to reflect on a replanning of the didactic method used in Portuguese Language and Literature classes based on the emergent demands of the classroom. Such demands relate to prejudice attitudes demonstrated by the students towards each other. From a reflection supported by theoretical references on Linguistics and Education - the theory of enunciation by Emile Benveniste, the perspective of linguistic education by Simões et al. (2012) and the theories of postcritical curriculum and planning represented by Santomé (1995), Corazza (1997) and T. T. Silva (2001) - we come up with two conclusions. First: it is essential to introduce in the school curriculum the cultures denied and silenced in didactic planning, in order to develop the critical and protagonistic literacies among the students (ROJO, 2014), preparing them for the exercise of citizenship and the respect for diversity. Second: a teaching method that rest on an enunciative conception of language and a perspective of linguistic education committed to the students' access to writing cultures contributes to the improvement of their skills and abilities related to the reading and writing of texts as social practices of language in use.
\end{abstract}

Keywords: Portuguese Language and Literature, Linguistic Education, Enunciation, Educational Replanning, Critical Literacy. 
A todos aqueles que lutam por uma escola cidadã $e$ representam, para as gerações do amanhã, um farol nestes tempos de trevas em que vivemos.

À Profa. Dra. Luciene Juliano Simões, cuja inspiração, tanto como supervisora de estágio quanto como referência teórica, marca cada página deste texto.

\section{Para início de conversa}

Em muitas escolas brasileiras, ainda vigora o modelo tradicional em que Língua Portuguesa e Literatura são ensinadas como duas disciplinas apartadas uma da outra. Há ainda instituições que acrescentam uma terceira disciplina, à qual chamam Redação, espaço reservado à leitura e à produção de textos, quase sempre encerrados nas tipologias textuais canônicas - narração, descrição e dissertação. Dessa fragmentação curricular sacramentada pelas escolas e, antes delas, pelos cursos de Letras com suas estreitas formações em língua/linguística e literatura/cultura -, decorre uma visão de ensino de língua e de literatura da qual desejo, desde já, afastar-me neste artigo.

Isso porque defendo, com Simões et al. (2012), uma proposta interdisciplinar de educação, na qual todos os componentes curriculares e não apenas os da área de Linguagens favoreçam o acesso dos alunos às culturas de escrita. Afinal, ler e produzir textos é compromisso de todas as disciplinas, pois a linguagem é transversal a todas as práticas sociais, e a língua escrita, historicamente vinculada à produção do conhecimento e à consolidação dos diferentes saberes disciplinares.

Mas uma pergunta que as autoras se colocam e que me coloco também é a seguinte: qual é a especificidade do ensino de Língua Portuguesa e Literatura (doravante, LPL) nesse contexto de interdisciplinaridade? Estou com elas na crença de que a resposta a essa questão repousa sobre as concepções de linguagem, de língua e de literatura assumidas, consciente ou inconscientemente, pelo docente.

Neste artigo, num movimento retrospectivo e reflexivo, retorno a uma experiência prática que conduzi como professor-pesquisador para, agora de um outro lugar enunciativo - o de pesquisadorprofessor -, refletir teoricamente sobre 0 planejamento, a execução e os resultados dessa experiência, realizada como estágio de docência numa turma de $7^{\circ}$ ano do Ensino Fundamental de uma escola pública do município de Canoas, na região metropolitana de Porto Alegre (RS).

Para tanto, organizo o texto do seguinte modo: inicialmente, exponho as concepções que nortearam minha prática pedagógica (cf. seção 1); em seguida, apresento o projeto de trabalho desenvolvido no estágio e problematizo os redirecionamentos impostos ao planejamento inicial pela realidade da turma em questão (cf. seção 2); na sequência, analiso a execução das tarefas pedagógicas (cf. seção 3); por fim, reflito sobre os resultados da experiência (cf. seção final).

\section{Sobre educação linguística, subjetividade e cidadania}

O observatório teórico desde o qual lanço meu olhar sobre o ensino-aprendizagem de LPL é a Teoria da Enunciação de Émile Benveniste, em diálogo com a perspectiva de educação linguística de Simões et al. (2012).

Nessa perspectiva, as disciplinas de Língua Portuguesa e Literatura integram um único componente curricular, pois:

a) ambas têm como objeto de estudo o texto;

b) ambas se entrecruzam na formação histórica do português como língua representativa de uma cultura;

c) ambas implicam uma à outra, sendo a língua portuguesa a matéria-prima da literatura, e a literatura, o uso da língua portuguesa mais ligado à produção de um conhecimento sobre si e sobre o mundo, isto é, mais ligado à construção da identidade individual e social.

Isso não significa que literaturas de línguas estrangeiras não possam ser trabalhadas na aula de 
LPL. O texto principal do projeto aqui descrito é, ele próprio, um expoente da literatura inglesa. Entretanto, uma vez traduzido para o português, passa a ter a língua portuguesa como a sua matéria-prima e a ser um uso da língua portuguesa produtor de saberes identitários individuais e sociais nessa língua.

A questão da identidade não é abordada por Benveniste como um objeto de teorização, mas comparece como um tema tangencial em sua reflexão acerca das relações entre a subjetividade, a socialidade e a linguagem ${ }^{1}$. Segundo o linguista, no artigo Estrutura da língua e estrutura da sociedade (1968), "a língua representa uma permanência no seio da sociedade que muda, uma constância que interliga as atividades sempre diversificadas. Ela é uma identidade em meio às diversidades individuais" (BENVENISTE, 1968/2006, p. 97).

Para Benveniste, a língua caracteriza-se por uma dupla natureza, individual e social, ao mesmo tempo imanente ao indivíduo e transcendente à sociedade. Assim, a apropriação da língua pelo homem envolve, de um lado, a subjetividade, isto é, a "capacidade do locutor para se propor como 'sujeito", a cada enunciação (BENVENISTE, 1958/2005, p. 286, grifo do autor), e, de outro, a socialidade, ou seja, "a integração da sociedade e a adequação ao mundo, e por consequência a normalização do pensamento e o desenvolvimento da consciência" (BENVENISTE, 1966/2006, p. 229).

Logo, podemos considerar a constituição subjetiva do homem como correlata de sua constituição social. Dito de modo mais simples, a identidade humana é uma construção linguageira, simultaneamente individual e coletiva: "É um homem falando que encontramos no mundo, um homem falando com outro homem, e a linguagem ensina a própria definição do homem" (BENVENISTE, 1958/2005, p. 285).

\footnotetext{
1 Tampouco é meu objetivo, neste artigo, produzir uma teorização enunciativa sobre o problema da identidade. Esta comparece, aqui, mais como um tema cultural organizador do planejamento didático - nos termos de Corazza (1997) - ou nos termos de Simões et al. (2012) - como um eixo temático estruturante de um projeto pedagógico. Para uma reflexão teórica mais aprofundada sobre a questão identitária à luz da Teoria da Enunciação de Émile Benveniste, remeto o leitor ao texto de C. L. da C. Silva (2016).
}

$\mathrm{Na}$ aquisição da linguagem, é segurando na mão do outro - em geral, na dos pais - que a criança dá seus primeiros passos na língua e na sociedade. Também na educação linguística é o outro - neste caso, o professor - que representa, para o aluno, a possibilidade de dar continuidade a esse percurso, rumo à descoberta de novos modos de se relacionar com a língua e com a sociedade.

$\mathrm{Na}$ visão benvenistiana, não há antinomia entre o eu e outro, entre o indivíduo e a sociedade, na medida em que a condição da subjetividade é a intersubjetividade; afinal, "a consciência de si mesmo só é possível se experimentada por contraste" (BENVENISTE, 1958/2005, p. 286).

A intersubjetividade, por sua vez, tem como condição "a sociedade como coletividade humana, base e condição primeira da existência dos homens" (BENVENISTE, 1968/2006, p. 96).

E todas essas noções - a subjetividade, a intersubjetividade e a sociedade - têm como condição a língua: "A sociedade não é possível a não ser pela língua; e, pela língua, também o indivíduo" (BENVENISTE, 1963/2005, p. 27).

Mas de que língua se trata? Não se trata apenas de uma língua-sistema, que constitui a identidade coletiva de uma dada comunidade de falantes, mas também de uma língua-discurso, constitutiva da identidade singular de cada indivíduo pertencente a essa comunidade, porque atualizada a cada enunciação, a cada "colocar em funcionamento a língua por um ato individual de utilização" (BENVENISTE, 1970/2006, p. 82).

Apesar de essa definição destacar a enunciação como individual, porque efetuada por um locutor que se propõe como sujeito ao enunciar, o ato enunciativo é também social, pois "Toda enunciação é, explícita ou implicitamente, uma alocução, ela postula um alocutário" (BENVENISTE, 1970/2006, p. 84). É, portanto, o ato de enunciação que torna possíveis a subjetividade, a intersubjetividade e a constituição recíproca de indivíduo e sociedade na e pela linguagem ${ }^{2}$.

\footnotetext{
2 A pedido do parecerista, para quem a língua - na perspectiva benvenistiana - é identidade e não produtora de identidades, escrevo esta nota para registrar minha interpretação distinta da
} 
Como pensar, então, o ensino-aprendizagem de LPL à luz de uma concepção enunciativa de linguagem como essa, em que língua, indivíduo e sociedade são indissociáveis?

Simões et al. (2012) apontam direções possíveis ao formularem o que denominam princípios para uma educação linguística comprometida com o letramento dos alunos: a cidadania, a fruição e a autoria ${ }^{3}$.

Por cidadania, as autoras entendem a

[...] copresença e interação entre homens livres na 'cidade'. A consciência do outro, ao mesmo tempo limite, espelho e aliado, remete, de um lado, à necessidade da busca de negociação de conflitos e, de outro, ao potencial de, em colaboração, superar o que seria possível a cada um realizar isoladamente. A escola é lugar privilegiado para a aprendizagem da solidariedade, para a formação do senso ético e para a participação. [...] é evidentemente na ação pela linguagem que se vão construindo esses valores. (SIMÕES et al., 2012, p. 44, aspas das autoras, negritos meus).

Essa concepção de cidadania remete à convivência, à troca, ao diálogo, enfim, à intersubjetividade constitutiva de qualquer sociedade e que só é possível via linguagem. Para Simões et al. (2012), é função da escola possibilitar o exercício da cidadania, que consiste na construção coletiva de um futuro, de uma vida melhor, de uma participação social presente e futura dos alunos no mundo alémmuros. Nesse sentido, a aula de LPL é um espaço favorecido, pois a cidadania só pode ser plenamente exercida com 0 acesso às culturas de escrita

sua. Entendo que a relação língua-identidade pode ser lida, em Benveniste, a partir das noções de língua-sistema e línguadiscurso: enquanto língua-sistema ("estrutura socializada", nas palavras do linguista), aquilo que é comum a uma comunidade de falantes, ela é uma identidade social; já enquanto línguadiscurso ("produção individual do falar", nos dizeres do autor), aquilo que define o próprio de cada um, ela é uma identidade individual. Vejo em ambas as "maneiras de ser língua" tanto a língua como identidade (social, no primeiro caso; individual, no segundo) quanto a língua como produtora de identidades (de um lado, a língua-sistema como produtora da identidade coletiva de uma determinada sociedade e cultura; de outro, a língua-discurso como produtora da identidade singular de um locutor que advém como sujeito a cada enunciação). Entretanto, como pontuo em nota anterior, teorizar sobre a identidade a partir de Benveniste extrapola os objetivos deste artigo, de forma que remeto o leitor novamente ao texto de C. L. da C. Silva (2016).

${ }^{3}$ Os parágrafos seguintes desta seção retomam e aprofundam o conteúdo presente na seção 2 de Oliveira (2017). construídas através da leitura e da produção de textos.

Lendo e produzindo textos, temos acesso a um universo de sentidos e visões de mundo, o que remete ao segundo princípio discutido pelas autoras, o da fruição:

Por fruição, [...] referimo-nos a ter a oportunidade de engajar-se subjetivamente com outras formas de expressão e de ler o mundo; referimo-nos a oportunizar na aula de português uma vivência direta dos textos que reserve aos alunos um espaço de liberdade. Uma vez garantido esse encontro livre e pessoal, a fruição possibilita também um espaço para a convivialidade, oportunizada pela arte literária e pela expressão linguística. (SIMÕES et al., 2012, p. 45, grifos meus).

A experiência direta do aluno com o texto, tanto na leitura quanto na escrita, é condição sine qua non para ele subjetivar-se, isto é, passar de locutor a sujeito ao ler e escrever. Creio, com Simões et al. (2012), que ler implica responder ao texto, e escrever, assumir um ponto de vista próprio: tanto em um caso quanto em outro está em jogo a fruição, o engajamento real do aluno com o texto, sem o qual dificilmente ele poderá formar-se como leitor e encontrar seus modos próprios de expressão na escola.

A partir da teoria benvenistiana, a leitura e a escrita podem ser concebidas como atos enunciativos, isto é, como atos por meio dos quais o locutor atualiza a língua na enunciação, acedendo à condição de sujeito de linguagem e participante da sociedade. O texto é justamente o discurso resultante da atualização da língua; o texto é, portanto, um produto da enunciação e uma prática socialmente situada.

Conforme as autoras, os princípios da cidadania e da fruição sustentam, ambos, um terceiro princípio: a autoria. Oportunizar, na aula de LPL, que o aluno assuma a sua própria voz é contribuir para a sua constituição como sujeito-autor:

Os elementos da fruição e da cidadania são, então, princípios educativos que se relacionam, em nosso componente curricular, à formação de autores. A ideia é pensar como certas propostas didáticas e como a avaliação 
escolar podem privilegiar a legitimação da voz do aluno e a responsabilização dele por suas ações de linguagem, frente aos que o cercam e à história a que pertence. (SIMÕES et al., 2012, p. 45, grifos meus).

Considerando tais concepções teóricas, que privilegiam uma proposta de educação linguística centrada na constituição da subjetividade e da cidadania do aluno, não podemos mais conceber língua como conjunto de regras gramaticais e ensino de língua como ensino dessas regras, tampouco podemos conceber literatura como história das escolas literárias e ensino de literatura como ensino dessas escolas. Língua e literatura passam a ser vistas, nessa proposta, como um legado cultural, mas, "sendo constituídas mais pelos valores do que pelas formas e estruturas em si, são um legado plástico, móvel, dinâmico e aberto" (SIMÕES et al., 2012, p. 39).

O que diz tudo isso à temática à qual nos propomos, isto é, à questão identitária na aula de LPL? A busca por uma resposta a essa pergunta constitui o objetivo da próxima seção.

\section{Sobre temas culturais no planejamento didático e culturas negadas e silenciadas no currículo escolar}

Tudo o que precede encaminha a pensar a identidade como tema central na aula de LPL. Mas a que se deve essa centralidade? Ora, a algo de que já falamos e que vale reiterar: à dupla natureza, individual e social, da língua, que se manifesta na relação com o outro e com a sociedade, pois o autorreconhecimento do eu está na dependência do reconhecimento do tu e dos valores socialmente partilhados.

Para Benveniste, o fundamento da subjetividade está no exercício da língua, ou seja, na enunciação, a qual revela quem somos e de que lugar falamos, atestando a inseparabilidade de língua e identidade: "Se quisermos refletir bem sobre isso, veremos que não há outro testemunho objetivo da identidade do sujeito que não seja o que ele dá assim, ele mesmo sobre si mesmo" (BENVENISTE,
1958/2005, p. 288), a cada enunciar, a cada tomada de palavra.

Da mesma maneira, a literatura, enquanto patrimônio cultural e histórico, veicula representações identitárias de indivíduos e sociedades. A educação linguística está, portanto, intimamente relacionada à construção da identidade do aluno, uma vez que as práticas de linguagem implicam o confronto com as representações de si e dos outros.

Nesse viés, cabe ao professor de LPL promover atividades que favoreçam a emersão da subjetividade dos alunos, o encontro deles com suas identidades individuais e sociais. As tarefas de leitura, produção de textos, reflexão linguística e reflexão sobre a literatura não podem "afetar as identidades dos alunos, permitindo-lhes forjar seus modos próprios de expressão, sem que [eles] possam experimentar, sem que haja fruição da busca por um projeto de interlocução, da luta com as palavras e do encontro com uma linguagem de fato sua" (SIMÕES et al., 2012, p. 45).

Em outros termos: quem ensina língua e literatura lida diretamente com a constituição da identidade pelo aluno enquanto alguém capaz de se sentir eu na língua, capaz de se sentir autorizado a assumir como sua essa língua. Logo, contribui para esse processo a problematização de questões identitárias como a morte, temática estreitamente vinculada à natureza humana e à construção da identidade individual e social do homem.

Foi a partir da opção por esse tema norteador - escolhido também em função do interesse dos alunos, apontado pela professora titular da turma, em contos de suspense e mistério - que selecionei o gênero estruturante e o texto principal do projeto de trabalho realizado durante meu estágio de docência. Foi selecionado o gênero "conto maravilhoso" e, como texto exemplar desse gênero, O Conto dos Três Irmãos, de J. K. Rowling, narrativa também presente no livro Harry Potter e as Relíquias da Morte, obra da mesma autora, e na sua adaptação para o cinema. Tal conto relata a aventura de três irmãos bruxos que recebem da Morte cada qual um presente, um artefato mágico que sela seu destino. 
A ideia inicial era analisar a tematização da morte em textos literários, como contos maravilhosos que a ficcionalizam de modo sobrenatural. Acontece que, nas primeiras aulas, presenciei três situações de discriminação que me levaram a repensar e, consequentemente, a replanejar parte do projeto elaborado. Na primeira, um aluno foi vítima de piada racista contada por uma colega. $\mathrm{Na}$ segunda situação, a mesma aluna que contara a piada racista constrangeu outro colega fazendo insinuações sobre sua sexualidade. $\mathrm{Na}$ terceira situação, um aluno insultou uma colega com ofensa machista.

Essas três situações de preconceito explícito, em sala de aula, coincidiram com a repercussão na mídia do caso da jovem vítima de estupro coletivo no Rio de Janeiro em maio de 2016. Assim, à luz tanto do contexto imediato da turma quanto do debate social suscitado pelo estupro coletivo, senti-me compelido a problematizar a gravidade do preconceito e de seus efeitos nocivos tanto para as vítimas quanto para a sociedade.

Mas como inserir o tema do preconceito no projeto sem modificá-lo totalmente, sem substituir seu eixo temático - a morte - e seu gênero estruturante o conto maravilhoso -? Com orientação da professora supervisora do estágio, encontrei na intolerância a ponte para estabelecer essa relação entre 0 preconceito e a morte. Afinal, a intolerância que está na origem de todo preconceito pode levar ao ódio, e este à morte.

Estabelecidas as relações temáticas necessárias para apresentar à turma um projeto de seu interesse, selecionei textos referentes a preconceitos de diferentes naturezas (cf. quadro 1), mais especificamente sobre racismo, machismo e homofobia, os quais haviam se presentificado em sala de aula. A seleção desses textos, bem como sua abordagem posterior em aula, foi orientada pelas reflexões de Corazza (1997), Santomé (1995) e T. T. Silva (2001) acerca, respectivamente, do planejamento didático a partir de temas culturais, das culturas negadas e silenciadas no currículo escolar e da relação entre currículo e identidade.
Corazza (1997) recusa as visões críticas do planejamento do ensino, tanto aquelas que 0 consideram gerencial, tecnicista e controlador das ações docentes e discentes (pedagogias marxistas) quanto aquelas que o julgam prejudicial à emergência espontânea de interesses, necessidades e capacidades dos estudantes (pedagogias liberais).

A autora concebe o planejamento como estratégia política de luta cultural e, por isso, filiado a uma noção de pedagogia como "prática de produção cultural, não mais implicada apenas na luta de classes, como também em tantas outras lutas, como as de raça, gênero, diferenças sexuais, identidades nacionais, colonialismo, etnia, populismo cultural, textualidade" (CORAZZA, 1997, p. 105).

Ao assumir esse entendimento mais amplo de paradigma educacional, Corazza (1997) vincula-se às teorias pós-críticas da educação, as quais defendem um planejamento didático pautado em temas culturais, como a morte e o preconceito. Tais teorias concebem o planejamento, mais precisamente, como:

a) ação pedagógica definidora dos saberes selecionados pelo currículo;

b) prática política comprometida com a contestação de significados que se pretendem e se instituem como totalizadores.

Sobre os saberes privilegiados pelos temas culturais, observa Corazza (1997):

Como forma de selecionarem e organizarem o currículo, os temas culturais trazem para a cena os "conhecimentos subjugados" (Foucault 1988), aqueles que nem foram pensados que poderiam vir a ser constituídos como conhecimentos escolares. Por isso, enfocam, deliberadamente, questões relativas a gênero, classe, raça, etnia, religião, identidade nacional, diferenças sexuais, discriminações de idade, colonialismo etc. e todos os conhecimentos que costumam integrar a cultura chamada de "popular". (CORAZZA, 1997, p. 127, aspas da autora, negrito $\mathrm{meu}$ ).

Nessa linha teórica, cada conteúdo, cada temática deve ser trabalhada sob diferentes olhares, discursos e significações. As diversas posições discursivas sobre um mesmo tema devem ser confrontadas, de modo que os alunos desenvolvam 
um olhar crítico quanto às relações de poder-saber que legitimam quais conhecimentos devem ser transmitidos na escola e também questionem o porquê do silenciamento de certos grupos sociais historicamente oprimidos, alguns dos quais parecem ser lembrados na instituição escolar apenas em dias específicos do ano, como o Dia da Consciência Negra.

Essa abordagem isolada e distanciada da realidade caracteriza o que Santomé (1995) chama de currículos turísticos. Para o autor, reservar um dia do ano à luta contra preconceitos é um equívoco no qual não pode cair uma política educacional que objetiva recuperar as vozes negadas no currículo escolar. Em suas palavras, um "currículo antimarginalização é aquele em que todos os dias do ano letivo, em todas as tarefas acadêmicas e em todos os recursos didáticos estão presentes as culturas silenciadas" (SANTOMÉ, 1995, p. 172).

$O$ autor critica o espaço cedido às culturas hegemônicas nas propostas curriculares, em detrimento de culturas marginalizadas. Como grupos ausentes na seleção do currículo escolar, ele cita as culturas hispânicas, o mundo infantil, o universo feminino, os grupos homossexuais, as etnias minoritárias ou sem poder, dentre outras. Conforme Santomé (1995), os currículos turísticos não podem ser admitidos, pois, além de abordarem superficialmente questões complexas como os preconceitos, conduzem à ideia equivocada de que a escola se encontra distante de tais problemáticas sociais, não sendo os alunos capazes de nelas intervir.

No quadro das teorias pós-críticas da educação, o currículo - e, acrescentaria eu, o planejamento - é uma questão de saber, poder e identidade (T. T. SILVA, 2001). Porque socialmente construído, o saber corporificado no currículo (e selecionado no planejamento) é parte inerente da dinâmica do poder. De acordo com T. T. Silva (2001), esta não se restringe às relações econômicas do capitalismo, incluindo lutas outras além da de classes, como as lutas culturais de etnia, raça, gênero, sexualidade, às quais subjaz uma concepção de identidade individual e social desvinculada do ideal crítico de sujeito pré-social contaminado pelos processos capitalistas de dominação.

Assim como não se pode mais, após as teorias pós-críticas, conceber o currículo apenas como grade curricular ou lista de conteúdos estáticos, ou pior, como currículo turístico, que cede espaço à luta contra preconceitos somente em dias isolados do ano letivo, não se pode mais conceber o planejamento como dispositivo disciplinador ou engessador. Tanto um quanto outro, tanto o currículo quanto o planejamento, são questões de saber, poder e identidade.

Feito esse percurso teórico, passemos à apresentação do projeto de ensino propriamente dito.

\section{No chão da sala de aula: o planejamento didático como saber-fazer}

Os dois quadros a seguir apresentam o projeto como um todo (cf. quadro 1) e cada uma de suas partes (cf. quadro 2). Vale dizer que os trechos grifados nesses quadros referem-se às modificações operadas no planejamento inicial em função das demandas emergentes da turma de estágio, demandas estas relacionadas a posturas preconceituosas demonstradas pelos alunos uns em relação aos outros. 
Quadro 1 - O projeto como um todo.

\begin{tabular}{|c|c|}
\hline $\begin{array}{ll}\text { 1. } & \text { Ensino } \\
& \text { Fundamental } \\
\end{array}$ & $7^{\circ}$ ano \\
\hline 2. Título do projeto & E se eu encontrasse a Morte? \\
\hline 3. Eixo temático & Morte e identidade \\
\hline 4. Problematização & $\begin{array}{l}\text { Como a morte define o humano e como o humano define a morte? Como a morte é tematizada em } \\
\text { diferentes mídias (literatura, cinema e imprensa)? Como a morte relaciona-se com o preconceito, } \\
\text { em suas diferentes naturezas? }\end{array}$ \\
\hline $\begin{array}{ll}\text { 5. Gênero } \\
\text { estruturante }\end{array}$ & Conto maravilhoso \\
\hline 6. Objetivos & $\begin{array}{l}\text { Produzir contos maravilhosos que tematizem a morte, refletindo sobre a sua relação com a } \\
\text { natureza humana e com a construção da identidade individual e social do homem. }\end{array}$ \\
\hline $\begin{array}{l}\text { 7. Textos para } \\
\text { leitura e } \\
\text { planejamento de } \\
\text { tarefas em aula }\end{array}$ & $\begin{array}{l}\text { Textos literários: } \\
\text { - O Conto dos Três Irmãos, de J. K. Rowling. } \\
\text { - A menina dos fósforos, de Hans Christian Andersen. } \\
\text { - A morta, de Guy de Maupassant. } \\
\text { Textos jornalísticos: } \\
\text { - Mulher é presa suspeita de injúria racial no Rio (Fonte: G1). } \\
\text { - Vítima de estupro coletivo no Rio conta que acordou dopada e nua (Fonte: G1). } \\
\text { - Polícia apura se jovem morto perto do Ibirapuera foi vítima de homofobia (Fonte: G1). } \\
\text { Infográficos: } \\
\text { - O reflexo do racismo no Brasil (Fonte: Innovare pesquisa). } \\
\text { - Violência de gênero (Fonte: Não me khalo). } \\
\text { - A homofobia no Brasil (Fonte: O Tempo Infográficos). }\end{array}$ \\
\hline $\begin{array}{ll}\text { 8. } & \text { Tarefas } \\
& \text { preparatórias }\end{array}$ & $\begin{array}{l}\text { Tarefas de preparação para a leitura com foco na introdução ao tema e ao gênero. } \\
\text { Tarefas de leitura e compreensão global com foco no tema dos textos. } \\
\text { Tarefas de estudo do texto com foco na estrutura dos textos. } \\
\text { Tarefas de reflexão linguística com foco na linguagem dos textos. } \\
\text { Tarefa de produção inicial com foco no diagnóstico dos conhecimentos da turma sobre o gênero } \\
\text { "conto maravilhoso" e a temática da morte. } \\
\text { Tarefa de produção textual final com foco na elaboração mais sofisticada de um conto } \\
\text { maravilhoso sobre a temática da morte. }\end{array}$ \\
\hline $\begin{array}{l}\text { 9. Competências } \\
\text { nucleares }\end{array}$ & $\begin{array}{l}\text { Ler textos de diferentes naturezas (literários, jornalísticos, multimodais), analisando a tematização } \\
\text { da morte em diferentes linguagens e mídias. } \\
\text { Escrever conto maravilhoso lançando mão de recursos linguísticos e textuais para produzir efeitos } \\
\text { de sentido compatíveis com esse gênero. } \\
\text { Praticar a fruição e a autoria na leitura e na produção de textos literários. } \\
\text { Refletir criticamente sobre preconceitos e sua relação com a temática da morte. }\end{array}$ \\
\hline $\begin{array}{l}\text { 10. Conteúdos } \\
\text { disciplinares }\end{array}$ & $\begin{array}{l}\text { Conto maravilhoso - propósito, interlocução, circulação, estrutura e linguagem. } \\
\text { Recursos linguísticos - tipos de discurso, verbos de dizer e pontuação do texto narrativo; } \\
\text { elementos espaço-temporais e progressão do texto narrativo; léxico específico do gênero } \\
\text { estruturante e dos seus textos de referência. }\end{array}$ \\
\hline
\end{tabular}

Fonte: Elaborado pelo autor. 
Quadro 2 - O projeto e suas partes.

\begin{tabular}{|c|c|}
\hline $\begin{array}{l}\text { Oficina } 1 \text { - Preparando o terreno } \\
\text { (aulas } 1 \text { e 2) }\end{array}$ & $\begin{array}{l}\text { Preparação para a leitura: introdução à temática da morte e ao gênero } \\
\text { "conto maravilhoso". } \\
\text { Leitura e compreensão global d'o Conto dos Três Irmãos. } \\
\text { Produção inicial: primeira escrita de um conto maravilhoso. }\end{array}$ \\
\hline $\begin{array}{l}\text { Oficina } 2 \text { - Mergulhando mais fundo (aulas } \\
3 \text { e 4) }\end{array}$ & $\begin{array}{l}\text { Estudo do texto: análise dos elementos da narrativa e da estrutura textual } \\
\text { do gênero "conto maravilhoso". } \\
\text { Reflexão linguística: estudo de vocabulário próprio ao universo } \\
\text { maravilhoso e de recursos linguísticos como tempos verbais, verbos } \\
\text { dicendi e pontuação da narrativa. }\end{array}$ \\
\hline $\begin{array}{l}\text { Oficina } 3 \text { - Pausa para retomar o fôlego } \\
\text { (aula 5) }\end{array}$ & $\begin{array}{l}\text { Entrega das produções iniciais acompanhadas de grades autoavaliativas e } \\
\text { bilhetes orientadores de reescrita. }\end{array}$ \\
\hline $\begin{array}{l}\text { Oficina 4-Ampliando horizontes } \\
\text { (aulas 6, 7, } 8 \text { e 9) }\end{array}$ & $\begin{array}{l}\text { Busca de conteúdos sobre o eixo temático: leitura de notícias e } \\
\text { infográficos sobre racismo, machismo e homofobia. } \\
\text { Produção - a pedido da escola para exibição aos pais na entrega dos } \\
\text { boletins - de cartazes com ilustrações d'O Conto dos Três Irmãos. }\end{array}$ \\
\hline $\begin{array}{l}\text { Oficina } 5 \text { - A bola é sua } \\
\text { (aulas 10, 11, 12, 13, 14 e 15) }\end{array}$ & $\begin{array}{l}\text { Leitura de dois outros textos de referência do gênero estruturante: os } \\
\text { contos A menina dos fósforos e A morta. } \\
\text { Produção final: escrita elaborada de um conto maravilhoso sobre a } \\
\text { temática da morte. } \\
\text { Seminário de socialização das produções da turma. } \\
\text { Feedback da turma sobre o projeto. }\end{array}$ \\
\hline
\end{tabular}

Fonte: Elaborado pelo autor.

O que chamei até aqui de projeto de trabalho ou projeto de ensino relaciona-se ao que Dolz et al. (2004) denominam sequência didática (doravante, SD). Para os autores, uma SD "é um conjunto de atividades escolares organizadas, de maneira sistemática, em torno de um gênero textual oral ou escrito" (DOLZ et al., 2004/2013, p. 82). Nessa proposta, a SD deve ter um gênero estruturante e seguir um esquema modular, isto é, ser organizada por módulos que visem à aquisição de competências e habilidades para a produção de texto pertencente ao gênero enfocado.

O quadro 2 sistematiza os módulos (oficinas) que constituíram a SD que apliquei em meu estágio de docência. Tais oficinas organizaram-se a partir de conteúdos procedimentais (SIMÕES et al., 2012), os quais consistem em procedimentos de didatização do trabalho com a linguagem em sala de aula e correspondem às tarefas preparatórias elencadas no item (8) do quadro 1. A seguir, apresento um breve relato das oficinas, bem como as tarefas realizadas em cada uma delas. 


\subsection{Oficina 1 - Preparando o terreno}

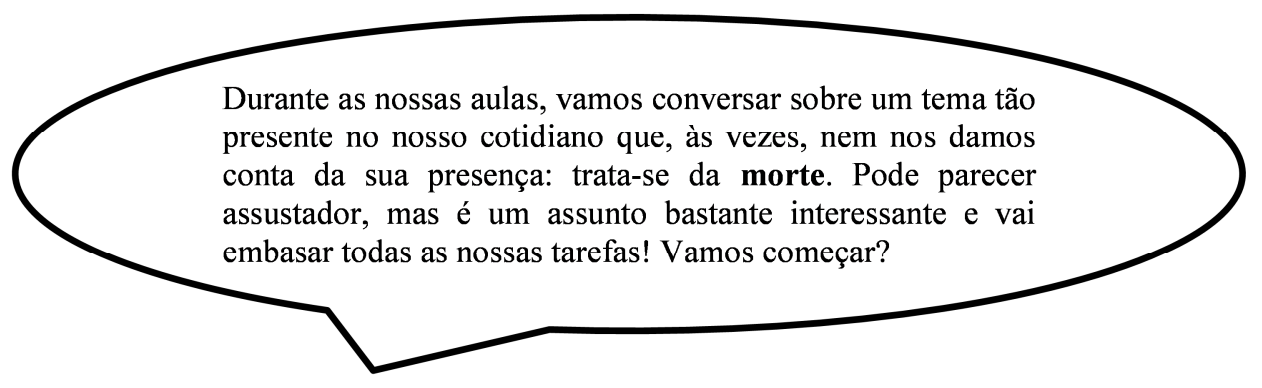

\section{Preparação para a leitura}

1. O livro A menina que roubava livros é narrado pela Morte. Leia o trecho abaixo, retirado da referida obra, e responda por escrito: por que você acha que os seres humanos assombram a Morte?

Tive vontade de dizer muitas coisas à roubadora de livros, sobre a beleza e a brutalidade. Mas que poderia dizer-lhe sobre essas coisas que ela já não soubesse? Tive vontade de lhe explicar que constantemente superstimo e submestimo a raça humana - que raras vezes a estimo (...) tudo o que pude fazer foi virar-me para Liesel Meminger e lhe dizer a única verdade que realmente eu sei. Eu a disse à menina que roubava livros e digo a você agora. Última nota de sua narradora: os seres humanos me assombram. (ZUSAK, 2007, p. 478).

2. Observe que a Morte se apresenta no texto como narradora. Você já ouviu falar em narrador? E em narrativa? Se sim, cite exemplos. Se não, formule alguma hipótese sobre o que podem significar essas palavras.

3. O gênero conto é um exemplo de texto narrativo. Você já leu algum conto? Se sim, qual ou quais? Se não, como você imagina que seja esse gênero de texto?

\section{Mãos à obra: leitura e compreensão global do texto}

1. Leia individualmente o texto $O$ Conto dos Três Irmãos.

2. Em seguida, sente em círculo com os colegas e acompanhe a leitura em voz alta feita pelo professor.

3. Após as duas leituras, discuta com a turma:

a) Qual é o propósito do texto?

b) Que tipo de conto é o texto?

c) Qual a relação desse conto com o tema que anunciamos no início da aula?

d) Quais são os três presentes dados pela Morte aos protagonistas do conto?

e) Se você pudesse escolher um desses três presentes, qual escolheria? E por quê?

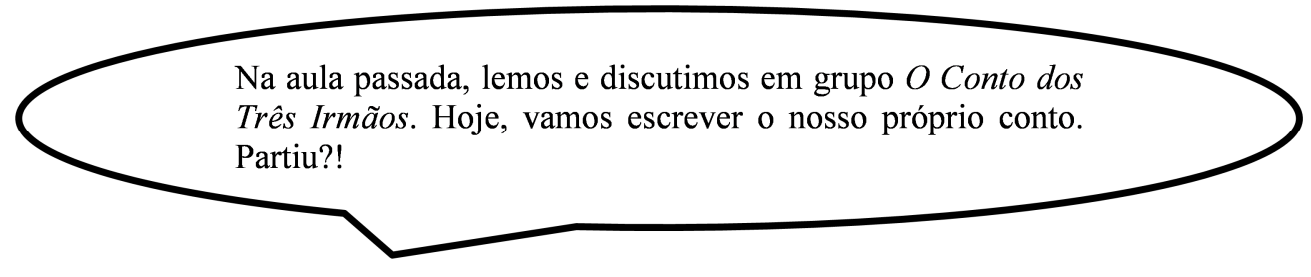

\section{Produção escrita inicial}

1. Escreva um conto a partir da provocação E se eu encontrasse a Morte? 
Esta oficina constituiu a etapa de apresentação da situação (DOLZ et al., 2004), cuja função é dupla (SIMÕES et al., 2012):

a) estabelecer um contrato pedagógico com a turma;

b) aproximar os alunos do gênero estruturante e do tema norteador.

O contrato pedagógico que estabeleci com os alunos implicou uma série de acordos referentes não só ao projeto que desenvolveríamos juntos nas semanas seguintes como também a algumas normas comportamentais que deveríamos adotar para um bom andamento das aulas.

Já a aproximação ao gênero e ao tema, busquei fazer da forma mais explícita possível, de modo que o grupo compreendesse exatamente o que faríamos nos dois meses que se seguiriam. Quanto ao gênero, não houve nenhuma reação específica, o que me levou a crer que os alunos não tinham conhecimentos prévios sobre conto maravilhoso. Quanto ao tema, surpreendi-me com uma reação negativa por parte da turma em relação à temática da morte. Isso me deixou ligeiramente surpreso, pois acreditava que tal tema interessaria aos alunos, os quais, segundo a professora titular de Português, haviam se envolvido bastante num projeto sobre contos de mistério e suspense realizado no ano anterior.

Essa impressão confirmou-se nas atividades de preparação para a leitura, cuja finalidade é aproximar o aluno do texto e ajudá-lo a começar a construir o sentido deste antes mesmo de realizar sua leitura propriamente dita. Conforme Simões et al. (2012, p. 148), nesse tipo de tarefa, "o grupo vai trabalhar sobre conhecimentos prévios necessários à leitura, sejam eles relacionados à temática do texto, ao gênero de discurso a que pertence ou aos recursos linguísticos necessários para sua compreensão".

No nosso caso, as atividades de pré-leitura buscaram verificar os conhecimentos dos alunos em relação ao gênero "conto maravilhoso" e à temática da morte, aspectos definidores d'O Conto dos Três Irmãos. Alguns alunos comentaram sobre os contos de mistério e suspense, mas nenhum disse já ter ouvido falar sobre conto maravilhoso.

Para a leitura d'O Conto dos Três Irmãos, foi entregue a cada aluno uma cópia do texto: num primeiro momento, os alunos o leram individual e silenciosamente; num segundo momento, pedi-lhes que sentassem em círculo, para estimular um clima de contação de histórias, e li em voz alta o conto.

Feitas as duas leituras, realizamos atividades de compreensão global do texto. Tarefas dessa natureza, segundo Simões et al. (2012), visam à compreensão global e à atitude responsiva dos alunos em relação ao texto, cuja leitura deve apresentar finalidades compatíveis, de um lado, com a circulação social do gênero do texto e, de outro, com o projeto pedagógico em curso.

Falar em circulação social de gêneros literários não é simples: a interlocução, o propósito e o circuito de leitura de tais gêneros não são tão evidentes como em gêneros jornalísticos ou publicitários, por exemplo. Assim, procurei elucidar aos alunos que a leitura literária é feita em busca da fruição, do prazer de ler e do divertir-se lendo, como é particularmente o caso do gênero "conto maravilhoso".

No que concerne à finalidade didática da leitura d'O Conto dos Três Irmãos, deixei claro aos estudantes ser este o texto principal de nosso projeto, que conciliava o gênero estruturante e o tema norteador, de forma que constantemente retornaríamos a ele ao longo das aulas.

As atividades de preparação para a leitura, leitura e discussão do conto ocorreram na primeira aula. Na segunda aula, realizamos a atividade de produção inicial, a partir da provocação $E$ se eu encontrasse a Morte?

Com exceção de três alunos, todos produziram o texto solicitado e o entregaram ao fim da aula. Tais produções, a despeito de problemas ajustáveis, adequaram-se ao gênero "conto maravilhoso": apesar de nunca terem ouvido falar sobre tal gênero, os alunos produziram suas narrativas tomando como referência $O$ Conto dos Três Irmãos, recém-lido. 
O relativo sucesso na produção inicial reforça o que Dolz et al. (2004, p. 86) afirmam sobre "todos os alunos, inclusive os mais fracos, [serem] capazes de produzir um texto oral ou escrito que responda corretamente à situação dada, mesmo que não respeitem todas as características do gênero visado".

Segundo os autores, a importância da produção inicial consiste na regulação da sequência didática tanto para os alunos - com a concretização das representações sobre o gênero estruturante projetadas na situação de apresentação - quanto para o professor - com o diagnóstico dos conhecimentos (sobre o gênero, sobre o tema e sobre os recursos linguísticos que precisam ser focalizados) que a turma já detém e os que ainda precisa adquirir para realização da produção final.

\subsection{Oficina 2 - Mergulhando mais fundo}

\section{Estudo do texto}

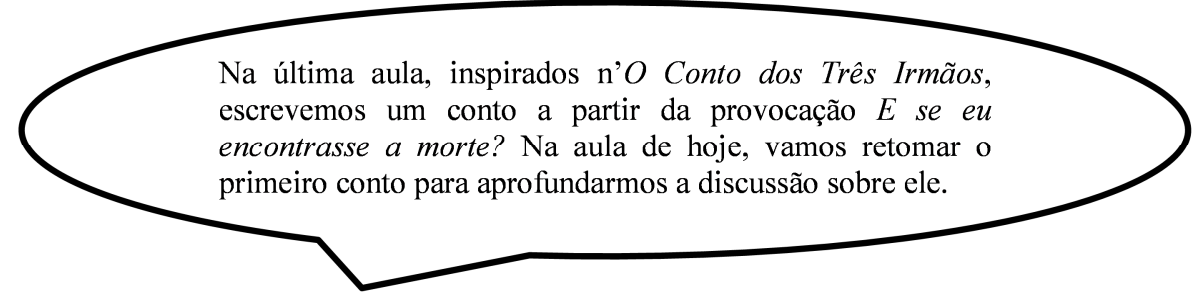

1. Releia O Conto dos Três Irmãos e responda em dupla:

a) O conto é introduzido por uma expressão característica de outro gênero textual: que expressão é essa? E qual seria esse outro gênero?

b) O conto tem três protagonistas: como cada um deles é caracterizado? Como cada um deles relaciona-se com a Morte e em que medida o tipo de relação que estabelecem com Ela determina o seu fim na narrativa?

c) O enredo tem início em um local onde estão presentes todos os personagens e, depois, desenrola-se em diferentes locais, acompanhando a trajetória dos personagens que se separam. Qual é a relação de cada um dos personagens com o local para onde se dirige? E qual é o único personagem que aparece em todos os locais?

d) O tempo em que se desenvolvem os acontecimentos narrados é especificado ou sugerido? Que elementos do texto fazem você chegar a essa conclusão?

e) Quem narra os acontecimentos? Podemos dizer que o narrador faz parte dos acontecimentos narrados?

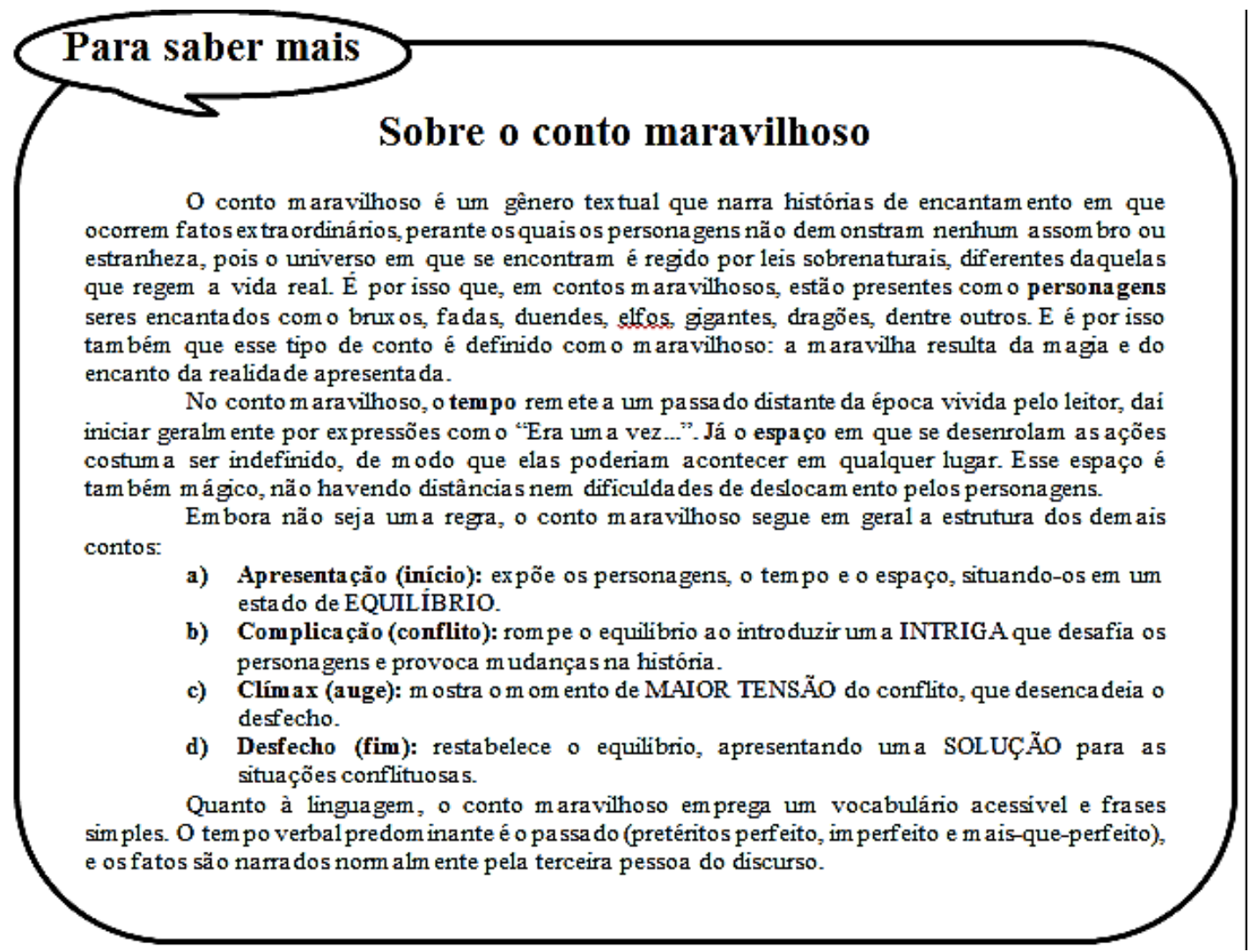




\section{Texto e linguagem}

2. Considerando as informações acima, responda:

a) Por que $O$ Conto dos Três Irmãos é um conto maravilhoso? Que elementos do texto fazem você chegar a essa conclusão? Aponte cinco palavras que ajudam a caracterizar o universo mágico do conto.

b) É possível perceber, no conto, a estrutura apresentação-complicação-clímax-desfecho? Se sim, aponte no texto cada uma dessas partes, utilizando a numeração em linhas para fazer esse apontamento.

c) Procure no dicionário o significado das palavras vadear (linha 2), vetusto (linha 12) e Entrementes (linha 37) e substitua-as por palavras que conservem o sentido das respectivas frases.

d) Observe a recorrência da palavra então no conto: que função você acha que essa palavra tem no texto?

e) Releia o segundo parágrafo (linhas 6-9): observe que é o narrador quem conta que "a Morte falou" e é também ele quem relata sua fala. Reescreva esse trecho dando voz à Morte e fazendo com que Ela diga diretamente, com suas próprias palavras, a fala relatada pelo narrador.

f) Observe os verbos fingiu (linha 7), disse e ganhara (linha 8)? Qual das três ações expressas por esses verbos aconteceu primeiro na narrativa?

g) Observe os verbos estavam (linha 5), queria (linha 19) e tornava (linha 31) e assinale a alternativa correta:

( ) Eles expressam ações acabadas, com início e fim precisos.

( ) Eles expressam ações inacabadas, com início e fim imprecisos.

h) Como é possível reescrever os verbos ganhara (I. 8), levara (I. 16) e arrebatara (I. 31), de forma que eles fiquem mais próximos do modo como nós falamos?

Esta oficina foi dedicada ao estudo do texto e à reflexão linguística a partir d'O Conto dos Três Irmãos.

O estudo do texto, de acordo com Simões et al. (2012), é um conteúdo procedimental distinto da leitura global, na medida em que consiste numa leitura analítica, mais dirigida aos detalhes do texto do que à sua compreensão como um todo. É o momento para analisar as relações entre os recursos linguísticos e literários e os sentidos do texto estudado. Tais questões centraram-se em elementos da narrativa, como personagens, tempo, espaço, narrador.

Em seguida, a partir de Köche et al. (2012), expus uma síntese sobre a estrutura textual do gênero "conto maravilhoso". Os alunos demonstraram uma dificuldade inicial para assimilar a estrutura do gênero, dificuldade esta que diminuiu nas aulas seguintes, com a leitura de outros textos de referência desse gênero, os quais oportunizaram a apropriação deste e de seus procedimentos de estruturação.

Embora eu tenha utilizado o sintagma reflexão linguística para me referir à quarta aula, esta deu continuidade ao estudo do texto iniciado na aula anterior, de modo que esteve mais focada numa investigação sucinta dos recursos linguísticos salientes no conto lido do que numa reflexão aprofundada e sistemática de formas e funções da língua com vistas a um projeto de reescrita.

Com efeito, Simões et al. (2012) colocam a reflexão linguística a serviço da reescrita, mas enfatizam também o seu papel no desenvolvimento das competências de escrita e de leitura dos alunos. De acordo com as autoras, o estudo de tópicos gramaticais deve estar sempre relacionado à língua em uso na leitura e na produção textual. Como já mencionado, as atividades de análise da linguagem realizadas nesta parte da SD detiveram-se sobre o conto lido, buscando refinar a leitura e os conhecimentos dos alunos acerca desse tipo de texto (narrativo) e gênero (conto maravilhoso).

Essas atividades enfocaram aspectos de vocabulário - atividades (a) e (c) -, coesão sequencial - atividade (d) -, tipos de discurso atividade (e) - e tempos verbais - atividades (f), (g) e (h). Os estudantes tiveram êxito na realização das atividades de léxico (a disponibilização de dicionários na própria sala de aula, que era uma sala temática de Linguagens, facilitou o trabalho com o vocabulário), sequencialização textual e discursos direto e indireto. Contudo, a turma não conseguiu compreender as questões de morfologia verbal.

Tentei, sem sucesso, relacionar os usos dos tempos da narrativa - pretéritos perfeito, imperfeito e 
mais-que-perfeito simples - aos usos que fazemos na oralidade, buscando fazê-los perceber que utilizamos esses tempos verbais na fala o tempo todo, mesmo o mais-que-perfeito, ainda que em sua forma composta.

Os tempos do subsistema do passado já estavam previstos no plano do projeto, no item (10), referente aos conteúdos disciplinares (cf. quadro 1), mas foi na leitura das produções iniciais que confirmei a necessidade de abordar tal tópico gramatical. Nas primeiras versões do conto maravilhoso, a grande maioria da turma apresentou problemas no estabelecimento de correlações verbo-temporais entre sequências narrativas, descritivas e dialogais.

Assim, num lado do quadro, desenhei uma tabela com quatro colunas, em cada uma das quais elenquei usos de formas verbais no perfeito, no imperfeito, no mais-que-perfeito simples e no maisque-perfeito composto, ocorrências presentes no conto principal e em alguns textos dos alunos que eu já havia lido.
No outro lado do quadro, tracei uma linha horizontal tomando o pretérito perfeito como eixo a partir do qual se projetam os tempos do subsistema do passado, estabelecendo relações de anterioridade - o perfeito em relação ao presente; o mais-queperfeito em relação ao perfeito - e continuidade/pontualidade - o imperfeito em relação ao perfeito; o perfeito em relação ao imperfeito (SAVIOLI; FIORIN, 1996).

Obviamente, não recorri a tais denominações na explicação, limitando-me à metalinguagem básica (perfeito, imperfeito e mais-que-perfeito), tampouco apresentei uma definição dos tempos verbais ou listei paradigmas de conjugação. O que tentei fazer foi conduzir os alunos a derivar entendimentos sobre a lógica do funcionamento desses tempos no interior do texto narrativo. Não consegui.

\subsection{Oficina 3 - Pausa para retomar o fôlego}

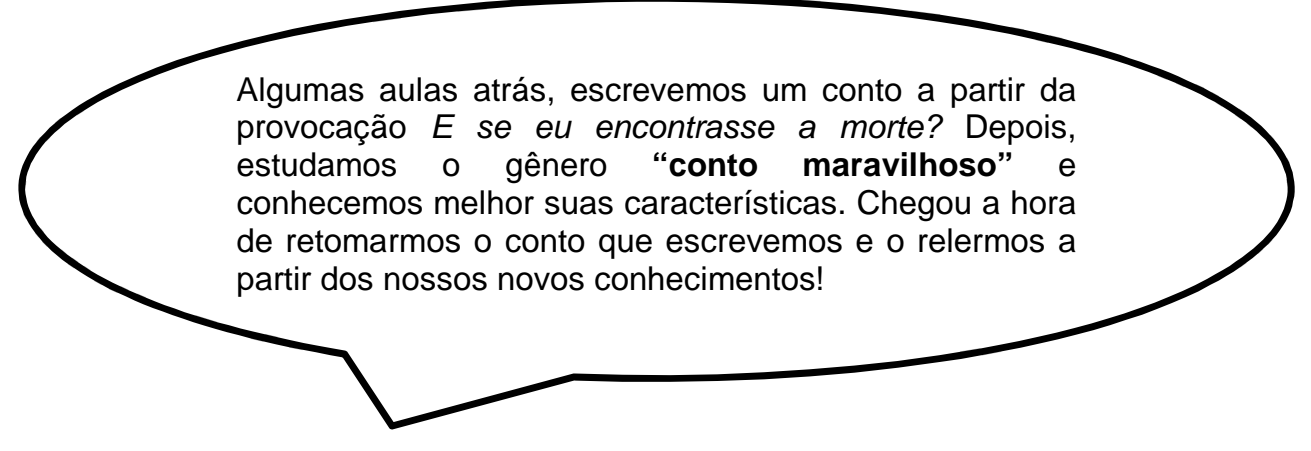

\section{Autoavaliação: o que posso dizer sobre o meu texto?}

Releia o conto que você escreveu e preencha o quadro a seguir:

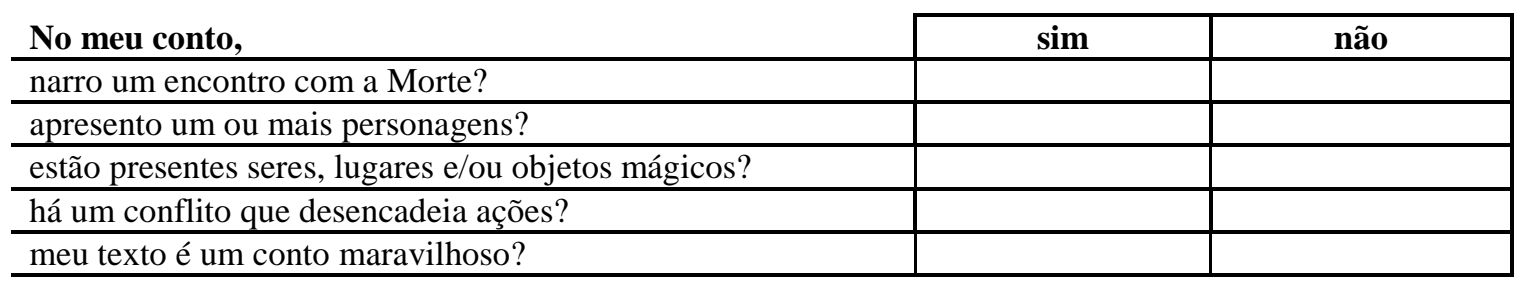

Se você não se lembra muito bem das características de um conto maravilhoso, retome o material da última aula e releia a parte "Para saber mais - Sobre o conto maravilhoso". 
Nesta oficina, entreguei aos alunos as produções iniciais lidas, porém sem marcações no corpo do texto nem atribuições de nota, e acompanhadas de uma grade de autoavaliação.

Entendo a avaliação como componente integrante do processo de ensino-aprendizagem e como atividade "processual, contínua e sinalizadora de que a responsabilidade pela aprendizagem é compartilhada por todos na sala de aula" (SIMÕES et al., 2012, p. 127). Essa visão de avaliação requer do professor, de um lado, reconhecer a autonomia do aluno para avaliar a própria aprendizagem e, de outro, diversificar os instrumentos avaliativos, sendo um desses instrumentos a autoavaliação.

Inicialmente, os estudantes estranharam o fato de receberem seus "trabalhos" sem nota e acompanhados de uma grade avaliativa que deveriam preencher eles próprios. Entretanto, pela atenção com que retornaram aos seus textos, pude constatar que a etapa de autoavaliação, feita a partir de perguntas formuladas com base nas características do gênero "conto maravilhoso" vistas na etapa de estudo do texto, veio sedimentar os conhecimentos já adquiridos sobre o gênero e oportunizar a ocupação de um novo lugar enunciativo pelos alunos: o lugar de leitores de si mesmos.

Outro instrumento avaliativo é o bilhete orientador de reescrita, entregue a cada aluno após a realização da autoavaliação, caso desejasse reescrever seu texto. De acordo com Simões e Farias (2013), o bilhete orientador de reescrita é um gênero catalisador a serviço da aprendizagem, através do qual o professor pode mediar o processo de aprimoramento da escrita do aluno e sua construção de conhecimentos sobre um gênero textual. Nesse sentido, "[m]andar bilhetes é uma prática pedagógica dinamizadora [...] porque proporciona ao par alunoprofessor um momento de diálogo mais individualizado, além de tornar a língua escrita uma forma de interação entre professor e aluno" (SIMÕES; FARIAS, 2013, p. 1).

Dessa maneira, ao se colocar como leitor interessado do texto do aluno, o professor o ajuda a se constituir autor, fazendo da sala de aula um espaço de interlocução e um ambiente colaborativo de aprendizagem de novos usos da linguagem.

Como dito anteriormente, as primeiras produções foram devolvidas sem marcações nem notas. Os apontamentos temáticos, textuais e linguísticos foram feitos exclusivamente nos bilhetes anexados aos textos. A exemplo das grades autoavaliativas, 0 recebimento de bilhetes aparentemente foi uma novidade para os alunos, que primeiramente também estranharam o procedimento, mas, a julgar pela curiosidade com que leram os bilhetes e pelos comentários positivos que se seguiram à leitura deles, percebi que gostaram de recebê-los.

Se a autoavaliação permitiu-lhes assumirem o papel de leitores de si próprios, os bilhetes testemunhos de uma leitura atenta de seus textos feita por um outro - pareceram também lhes possibilitar a ocupação de um novo lugar enunciativo: o lugar de sujeitos-autores.

Tais movimentos enunciativos do aluno em práticas avaliativas em sala de aula são discutidos, à luz da Teoria da Enunciação de Benveniste, por Knack e Oliveira (2017). Para os autores, a avaliação textual é um duplo ato de enunciação, pois envolve a leitura de um texto e a produção de um texto de retorno ao texto lido. Esse duplo ato realiza-se por meio do que eles designam como instâncias enunciativas de avaliação: a instância de avaliação professor-aluno, a instância de avaliação aluno-aluno e a instância de autoavaliação. Dessas três, devido ao tempo limitado do estágio, apenas a segunda também conhecida como avaliação entre pares - não foi nele contemplada.

Conforme Knack e Oliveira (2017), na instância de avaliação professor-aluno, a re-significação dos modos de enunciação do aluno, isto é, a mudança qualitativa em sua relação com a escrita "está na dependência da enunciação de retorno do professor, representante da cultura acadêmica [escolar] e, por isso, o indicador por excelência dos caminhos a serem percorridos em busca de tal re-significação" (KNACK; OLIVEIRA, 2017, p. 714, grifo dos autores, acréscimo meu). 
Já na instância de autoavaliação, o aluno deve distanciar-se do seu texto para lê-lo como leria o texto de outra pessoa. Nesse gesto de distanciamento,

parece haver um desdobramento do eu, em que o aluno ocupa as duas posições do quadro figurativo, a de locutor-avaliador e a de alocutário-avaliado. A ocupação simultânea desses dois lugares de enunciação exige dele um deslocamento da posição de interlocutor do ato de avaliação para a de protagonista desse ato e, ao mesmo tempo, a manutenção da posição de interlocutor para poder avaliar o seu próprio texto. Essa autoavaliação obriga um exercício de distanciamento, o qual faz dela um diálogo interiorizado, entre um eu leitor e um eu escrevente. (KNACK; OLIVEIRA, 2017, p. 715, grifos dos autores).
Ambas as instâncias enunciativas de avaliação visam à reescrita do texto avaliado e destacam a função mediadora da língua nas trocas intersubjetivas. No entanto, Knack e Oliveira (2017) ressaltam que a qualificação do texto do aluno a partir da reescrita orientada pela avaliação é somente um efeito a curto prazo das instâncias avaliativas, cujo potencial pedagógico reside, de fato, nos seus efeitos a longo prazo: enquanto a avaliação professor-aluno contribui para a constituição do aluno como produtor de textos, a autoavaliação contribui para a sua constituição como leitor do seu próprio texto ${ }^{4}$.

\subsection{Oficina 4 - Ampliando horizontes}

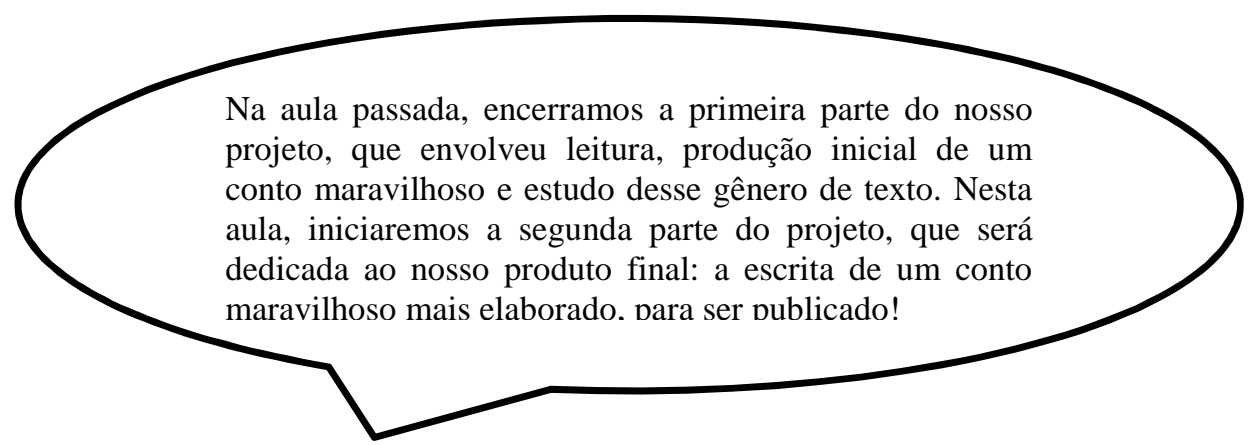

\section{Busca de conteúdos: o preconceito também mata!}

1. Leia os três dados abaixo e reflita: qual a relação das realidades apresentadas por eles com a temática do nosso projeto (morte)?

"Uma mulher é estuprada no Brasil a cada 11 minutos."

Fonte: Fórum Brasileiro de Segurança Pública (FBSP).

"Jovem negro tem 2,5 vezes mais chance de ser assassinado do que branco."

Fonte: Fórum Brasileiro de Segurança Pública (FBSP).

"O Brasil é o país que mais mata travestis e transexuais no mundo. Entre janeiro de 2008 e março de 2014 , foram registradas 604 mortes no país."

Fonte: Transgender Europe (TGEU).

2. O professor dividirá a turma em três grupos, cada um dos quais deverá ler um texto jornalístico e um infográfico, discuti-los e, em seguida, apresentá-los ao restante da turma. Leia e discuta os textos com seu grupo pensando na questão acima: qual a relação das realidades apresentadas por eles com a temática do nosso projeto (morte)? Em seguida, prepare-se para resumir oralmente o texto para os colegas dos demais grupos, lembrando-se de que eles não o leram.

\footnotetext{
${ }^{4}$ Quanto a essa reflexão enunciativa sobre leitura, escrita e avaliação, cabe uma ressalva: Benveniste não abordou tais temas como aqui os estou abordando, com foco em suas dimensões textual e pedagógica. Assim, trata-se de deslocamentos por mim operados, a partir dos princípios gerais da teorização benvenistiana, para os campos do texto e do ensino-aprendizagem de língua materna. Para problematizações mais detidas sobre tais deslocamentos, ver Knack e Oliveira (2017) e Oliveira (2018).
} 
Esta oficina deu início ao ciclo de produção textual. Enquanto o ciclo de leitura consistiu na primeira parte da SD (oficinas 1, 2 e 3), contemplando as etapas de leitura global, produção inicial, estudo do texto, reflexão linguística e autoavaliação, o ciclo de produção textual consistiu na segunda parte da SD (oficinas 4 e 5), cujo foco foi a escrita final de um texto adequado à temática da morte e ao gênero "conto maravilhoso".

Refletindo acerca do planejamento de tarefas de produção de textos, Simões et al. (2012) enumeram três procedimentos importantes na didatização da escrita, dos quais o primeiro está relacionado ao tema norteador e os dois outros, ao gênero estruturante:

a) a busca de conteúdos para a produção;

b) o foco em um gênero do discurso;

c) a leitura de textos de referência desse gênero.

Procedimento constitutivo das práticas de escrita, a busca de conteúdos objetiva a ampliação dos horizontes do aluno no que concerne à temática do projeto, através da localização, da seleção e da consulta a diversas fontes de informação sobre o assunto, incluindo a leitura de textos não pertencentes ao gênero estruturante. Tal procedimento deve procurar também estabelecer relações entre o eixo temático do projeto e o cotidiano dos alunos, aproximando o tema de sua vida, de sua realidade concreta.

Foi o que tentei fazer, ao trazer para a sala de aula textos sobre racismo, machismo e homofobia, a fim de problematizar e desnaturalizar os preconceitos frequentes na turma. Preconceitos estes que podem levar - e frequentemente levam - à morte, tema de nosso projeto.

Para tanto, entreguei aos alunos um handout com dados estatísticos sobre o estupro e o genocídio de negros, travestis e transexuais no Brasil, o que funcionou como uma espécie de preparação para a leitura dos textos seguintes. Os números alarmantes provocaram consternação entre os estudantes, que pareceram confrontados pela primeira vez com a gravidade dos preconceitos que eles próprios praticavam cotidianamente.

$\mathrm{Na}$ sequência, dividi a turma em três grupos, distribuindo a cada grupo uma notícia de jornal sobre um tipo de preconceito, uma sobre racismo (Mulher é presa suspeita de injúria racial no Rio), outra sobre violência de gênero (Vítima de estupro coletivo no Rio conta que acordou dopada e nua) e outra ainda sobre homofobia (Polícia apura se jovem morto perto do Ibirapuera foi vítima de homofobia).

Além dos textos jornalísticos, cada grupo recebeu um infográfico sobre o seu tipo de preconceito. Então, orientei os grupos a lerem as notícias e os infográficos, discuti-los entre seus integrantes, buscando relacionar o conteúdo dos textos ao tema do nosso projeto, e prepararem-se para resumir esse conteúdo para o restante da turma, considerando que os interlocutores-colegas não teriam lido os textos dos demais grupos.

A etapa de busca de conteúdos foi interrompida nas aulas 7 e 8 em função de uma demanda da escola: a direção solicitou que cada turma preparasse algo para apresentar aos pais na entrega dos boletins. Conjuntamente, os alunos e eu decidimos confeccionar cartazes com ilustrações d'O Conto dos Três Irmãos, o que nos tomou duas aulas, mas aproximou os alunos do tema e do gênero do nosso projeto de um modo outro além da leitura e da escrita.

A confecção de tais cartazes e a produção de tais ilustrações vão ao encontro dos letramentos multissemióticos, cuja inserção nas práticas letradas escolares é defendida por Rojo (2014). Segundo a autora, a consideração desses letramentos supõe o enfoque de múltiplas linguagens e semioses (oral, escrita, musical, imagética, corporal, matemática, digital) e, consequentemente, a necessidade de um trabalho interdisciplinar na escola. Trata-se de desenvolver no aluno competências e habilidades para o uso das variadas linguagens (verbais, não verbais, multimodais). A incorporação de práticas letradas multissemióticas, conforme Rojo (2014), é requisito para agir na vida contemporânea através da 
produção e da compreensão de discursos em diferentes contextos, mídias e modalidades.

Também faz parte dos letramentos multissemióticos a leitura de textos multimodais (que mesclam informações verbais e não verbais), como os infográficos sobre preconceitos lidos na aula 6 e relidos na aula 9 , em que demos prosseguimento à oficina 4.

Nessa aula, cada grupo releu as suas respectivas notícias e infográficos, discutindo-os novamente e, dessa vez, apresentando-os em seguida aos demais colegas. A leitura dos textos sobre racismo, machismo e homofobia, seguida do estabelecimento de relações desses temas com a temática do projeto e da socialização das impressões de cada grupo com o restante da turma, suscitou um debate acalorado em aula.

Nenhum aluno, mesmo os que haviam anteriormente submetido colegas a tais descriminações, questionou o estatuto de preconceito atribuído aos casos de racismo e homofobia relatados nos textos. Todavia, muitos estudantes contestaram a atribuição desse estatuto ao caso do estupro coletivo ocorrido no Rio de Janeiro e representativo, em nossa atividade de busca de conteúdos, da violência de gênero decorrente do machismo e da objetificação sexual do corpo feminino.
Para esses alunos, a jovem vítima do estupro coletivo "mereceu" o ocorrido, pois "pediu" para ser violentada ao supostamente frequentar favelas e relacionar-se com muitos homens dessas comunidades.

Foi árdua a tentativa de fomentar uma reflexão mais crítica acerca do crime cometido pelo grupo de estupradores. À medida que alguns alunos se pronunciavam mais firmemente contra a vítima, pude perceber, pelos seus comentários, que suas opiniões eram fortemente influenciadas pela religião e pelo conservadorismo familiar.

A constatação dessa realidade me levou a questionar os limites éticos de meu próprio papel como docente: se, por um lado, tenho o compromisso profissional de promover os letramentos críticos em sala de aula, por outro, não devo respeitar a liberdade de crença e de opinião dos alunos? Mas e quando essa liberdade de expressão é confundida com liberdade de opressão e mascara sentidos totalitários?

Ainda não encontrei - se é que um dia encontrarei - respostas a essas questões.

\subsection{Oficina 5 - A bola é sua}

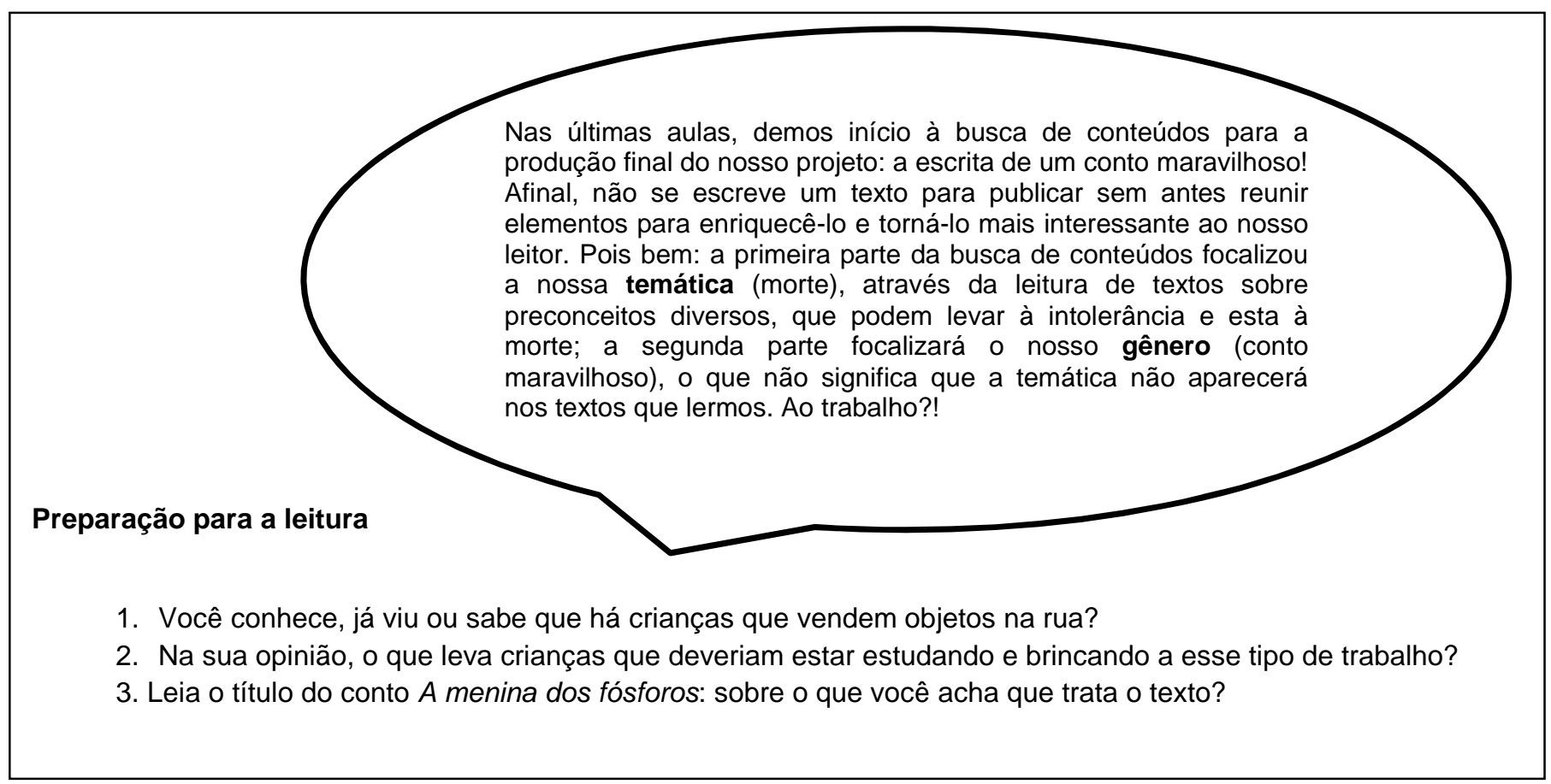




\section{Mãos à obra: leitura e compreensão global do texto}

1. Leia individualmente o conto $A$ menina dos fósforos.

2. Em seguida, sente em círculo com os colegas e acompanhe a leitura em voz alta feita pelo professor.

3. Após as duas leituras, discuta com a turma:

a) Qual a relação desse texto com a temática e o gênero do nosso projeto?

b) Quais são as semelhanças e as diferenças entre esse texto e o Conto dos Três Irmãos?

c) As suas hipóteses sobre o texto, feitas a partir do título, foram confirmadas após a leitura?

d) Você acha que o conto se passa em uma época atual ou mais antiga? Que elementos do texto fazem você chegar a essa conclusão?

e) Como morre a menina que protagoniza o conto?

f) Você acha que as imagens vistas pela criança através dos fósforos são reais? Ou seriam ilusões de sua mente cansada, com frio e com fome? Ou seriam ainda acontecimentos já ocorridos na "outra vida"?

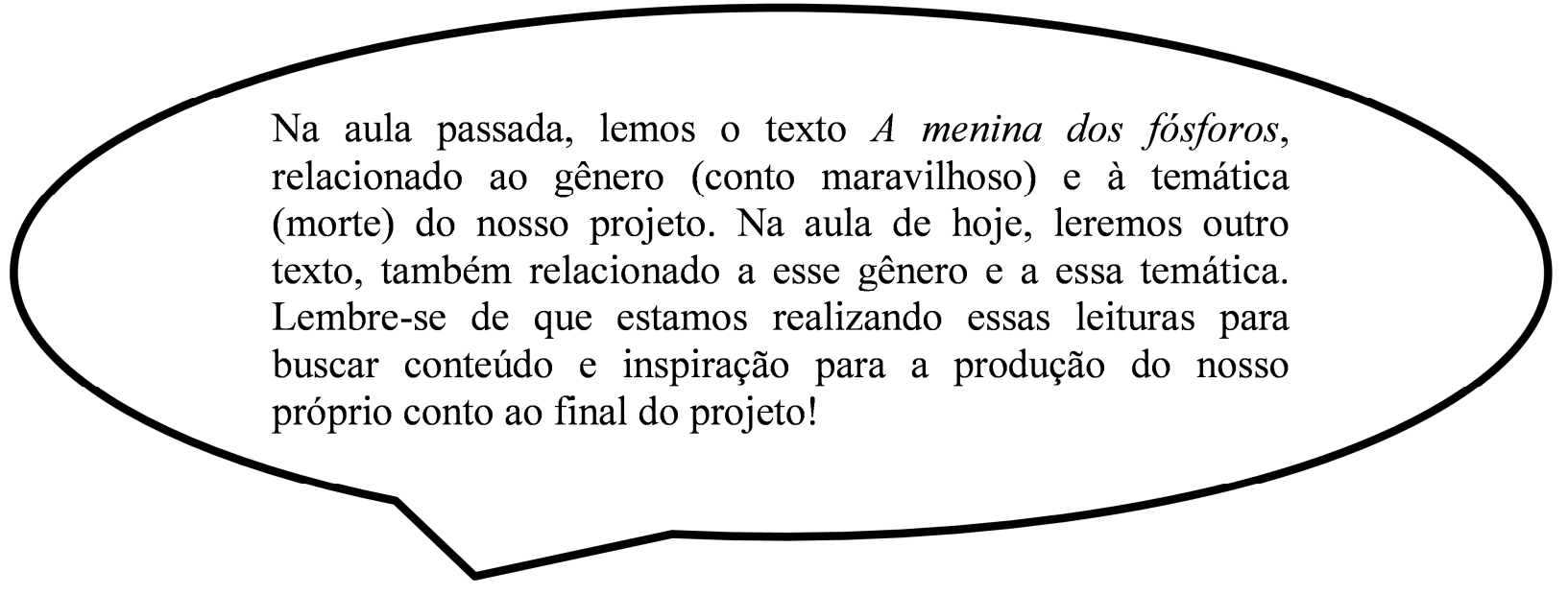

\section{Preparação para a leitura}

1. Você já visitou algum cemitério? O que acha de locais assim?

2. Leia o título e o primeiro parágrafo do conto $A$ morta: sobre o que você acha que trata o texto?

\section{Mãos à obra: leitura e compreensão global do texto}

1. Leia individualmente o conto $A$ morta.

2. Em seguida, acompanhe a leitura em voz alta feita pelo professor.

3. Após as duas leituras, discuta com a turma:

a) Qual a relação desse texto com a temática e o gênero do nosso projeto?

b) Quais são as semelhanças e as diferenças entre esse texto e os outros dois que já lemos: $O$ Conto dos Três Irmãos e A menina dos fósforos?

c) As suas hipóteses sobre o texto, feitas a partir da leitura do título e do primeiro parágrafo, foram confirmadas após a leitura completa?

d) O autor do conto utiliza bastante um sinal de pontuação específico: que sinal é esse? E qual é a sua contribuição para o sentido global do texto?

e) Como o ser humano, de modo geral, é retratado no conto? Que elementos do texto fazem você chegar a essa conclusão? 
Nesta oficina, após ter sido levada a cabo a busca de conteúdos sobre a temática da morte e suas relações com os preconceitos de raça, gênero e orientação sexual, foi a vez de considerar dois outros procedimentos didáticos das aulas de escrita, mais voltados ao gênero estruturante: o foco em sua estrutura textual e a leitura de textos exemplares dele.

A focalização do trabalho e da atenção do aluno em um gênero se nos impõe como uma necessidade pedagógica quando assumimos a concepção de sequência didática de Dolz et al. (2004) enquanto conjunto de atividades direcionadas à produção de um gênero de texto. Tal gênero deve estruturar todo o trabalho realizado em sala de aula, de modo que todas as tarefas - de leitura, de estudo do texto, de reflexão linguística, de reflexão sobre a literatura e de produção textual - precisam girar em torno desse gênero focal.

Escolhido o gênero estruturante, faz-se necessário selecionar textos pertencentes a esse gênero e compor um acervo que coloque o aluno em contato com o gênero, a fim de que ele possa apreender suas formas e funções. Para Simões et al. (2012, p. 166), é "importante que os alunos tenham acesso a um número razoável de textos de referência, pertencentes ao gênero estruturante, num conjunto de aulas que pretende viabilizar a aprendizagem da leitura e da escrita desse gênero: três boas tarefas com diferentes textos, no mínimo".

Em nosso projeto, além d'O Conto dos Três Irmãos, dois outros contos foram selecionados para leitura como textos de referência: o conto $A$ menina dos fósforos, de Hans Christian Andersen, lido e discutido na aula 10; e o conto $A$ morta, de Guy de Maupassant, lido e discutido na aula 11. Tais contos foram retirados de Köche et al. (2012), que os apresentam em capítulos distintos, o primeiro no capítulo sobre o gênero "conto maravilhoso" e o segundo no capítulo sobre o gênero "conto fantástico".

As autoras argumentam que o maravilhoso e o fantástico são gêneros vizinhos, ambos tendo o sobrenatural como elemento principal do enredo, mas se distinguindo pela abordagem desse elemento. No maravilhoso, o sobrenatural é aceito sem assombro nem questionamento por parte dos personagens. No fantástico, ele produz um efeito de incerteza e hesitação nos personagens.

Ao trazer para a aula o conto $A$ morta, esclareci aos alunos quanto à presença da dúvida do protagonista em relação aos eventos sobrenaturais por ele testemunhados, o que diferencia esse texto dos dois outros, $O$ Conto dos Três Irmãos e A menina dos fósforos, cujos personagens lidam naturalidade com o surreal.

Considerei adequado distinguir os gêneros recorrendo a essa característica e aos seus nomes, mas não fiz disso uma pauta em aula e expliquei aos alunos que, em sua produção final, eles poderiam escolher se escreveriam um conto maravilhoso ou um fantástico, a depender da reação de seus personagens aos acontecimentos sobrenaturais.

As atividades realizadas a partir desses dois contos centraram-se nas etapas de preparação para a leitura e de leitura e compreensão global. Como observam Simões et al. (2012, p. 154) referindo-se à prática da leitura, "as tarefas indispensáveis são de contextualização (preparação) e estabelecimentos de finalidades (por meio de propostas de leitura global)". Logo, nem todos os textos lidos em aula devem necessariamente passar pelas etapas de estudo do texto e reflexão linguística (leituras mais detalhadas).

Ainda assim, a leitura de tais contos propiciou momentos de análise textual - como na distinção entre os gêneros maravilhoso e fantástico - e linguística - como na atividade (d) do conto A morta, que solicitou a identificação de um sinal de pontuação (o ponto de exclamação) empregado numerosas vezes pelo narrador em primeira pessoa e o reconhecimento da contribuição desse sinal para a construção do sentido global do texto.

Tal atividade com o ponto de exclamação possibilitou uma breve explanação sobre outros sinais de pontuação, como a vírgula na segmentação de orações, o ponto final na segmentação de períodos e o travessão e as aspas na delimitação de sequências dialogais na narrativa. Esse último tópico oportunizou ainda uma abordagem sucinta dos principais verbos 
dicendi presentes nos três contos lidos e sua função na demarcação textual das vozes dos personagens.

Apesar de problemas de uso da vírgula persistirem nas produções finais, foi visível o salto qualitativo destas em relação às produções iniciais no que tange à utilização do ponto final na divisão de períodos (dois alunos haviam escrito suas produções iniciais sem lançarem mão de absolutamente nenhum ponto final) e ao emprego de travessões e aspas na distinção de falas.
Em linhas gerais, a turma logrou realizar as atividades de leitura e compreensão global dos contos A menina dos fósforos e A morta, demonstrando certa dificuldade apenas nessa atividade referente ao sinal de pontuação e na seguinte, a atividade (e), que exigiu dos alunos uma sensibilidade mais apurada para perceber o retrato pessimista que é feito do ser humano no texto de Guy de Maupassant.

\section{Produção escrita final}

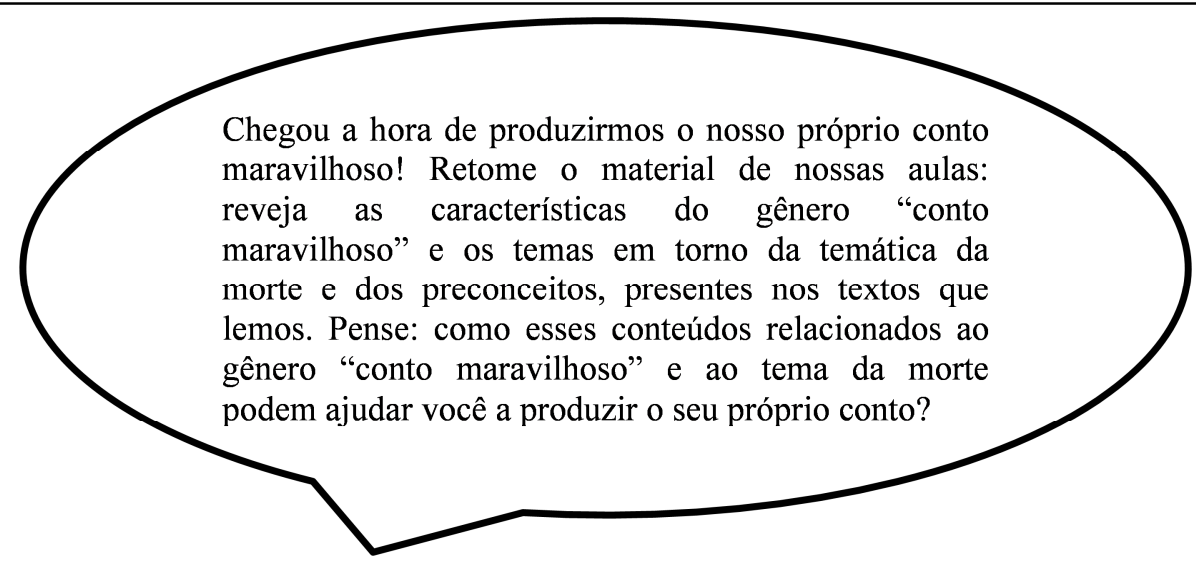

1. Escreva um conto maravilhoso sobre a temática da morte que apresente a estrutura do gênero (apresentação-complicação-clímax-desfecho) e seus elementos característicos (personagens, lugares e tempo relacionados a um universo mágico). Você pode reescrever a produção inicial, aprimorando-a, ou escrever um novo conto!

As últimas quatro aulas do estágio foram dedicadas à produção final.

$\mathrm{Na}$ aula 12, após sistematizar no quadro o percurso que havíamos empreendido do início do projeto até aquele momento, retomando questõeschave para a produção final (como as principais características temáticas, textuais e linguísticas dos textos lidos), entreguei-lhes todos os materiais utilizados ao longo das aulas - as cópias dos contos, das notícias e dos infográficos lidos, bem como os handouts das tarefas preparatórias (reproduzidos neste artigo) - e pedi-lhes que retomassem tais materiais a fim de reunir elementos para a sua produção final.

Além disso, recordei-lhes da importância de ter em mente, na escrita do texto, um interlocutor definido, no caso os colegas e o professor, que ouviriam a leitura do texto em voz alta, a ser realizada pelos alunos que se dispusessem a socializar suas produções com o grupo na aula final.

As aulas 13 e 14 foram inteiramente reservadas à produção dos contos individuais. $\mathrm{Na}$ aula 15, nosso último encontro, devolvi as produções finais aos alunos (que as tinham entregues no encontro anterior), acompanhadas de bilhetes individualizados, nos quais busquei falar mais dos textos do que nos bilhetes que acompanharam as produções iniciais. Esse "falar mais" contemplou não apenas questões temáticas, mas também textuais e linguísticas. Tal mudança deve-se à evolução mesma da qualidade e da extensão dos últimos textos em relação aos primeiros. 
Três alunos se dispuseram a socializar suas produções, desde que eu as lesse em voz alta e não eles. Pude notar que essas leituras, ainda que de poucos contos, garantiram momentos finais de descontração e também de percepção, por parte dos estudantes, de que seus textos podem "ir para o mundo", mesmo esse "mundo" sendo o microcosmo da sala de aula.

Antes de dispensar os alunos e encerrar as atividades, pedi-lhes que dessem um feedback do projeto, respondendo à seguinte questão posta no quadro: o que você achou do nosso projeto sobre o gênero "conto maravilhoso" e a temática da morte? $\mathrm{Na}$ seção seguinte, a título de conclusão, comento algumas respostas a essa pergunta e apresento as considerações finais desta reflexão.

\section{A aula de Língua Portuguesa e Literatura: um espaço-tempo enunciativo para a constituição do aluno como sujeito de linguagem e participante da sociedade}

A experiência docente aqui relatada foi orientada por pressupostos teóricos e, sobretudo, metodológicos advindos de uma pedagogia da língua direcionada ao desenvolvimento do letramento dos alunos. Isso não é uma missão fácil.

A elaboração de tarefas didáticas coerentes com as concepções de linguagem, língua, literatura e ensino de língua e literatura assumidas, bem como a vivência do cotidiano escolar - com todos os desafios impostos pelo desinteresse, pela indisciplina e pelas dificuldades dos alunos e, ainda, pelas demandas emergentes em sala de aula, como as oriundas das situações de preconceito explícito que encaminharam um replanejamento do projeto - exigiu não somente formação especializada na área de linguagem, mas também sensibilidade.

Sensibilidade para efetivar uma prática condizente com as teorias de referência. Sensibilidade para saber avaliar o que precisava ser modificado no planejamento inicial e operar as modificações necessárias. Sensibilidade para lidar com as relações humanas estabelecidas em sala de aula e com a (busca pela) desnaturalização de valores preconceituosos cristalizados.

Apesar de alguns insucessos, como a reflexão sobre os tempos verbais da narrativa e a falta de tempo para a reescrita das produções finais, acredito que obtive um saldo positivo no estágio como um todo. O relativo êxito dos estudantes na realização das tarefas de preparação para a leitura, leitura e compreensão global, produção inicial, estudo do texto, reflexão linguística (envolvendo recursos outros além dos tempos verbais, como pontuação e tipos de discurso), autoavaliação, busca de conteúdos e produção final atesta a potencialidade pedagógica de tais procedimentos e a viabilidade de transposição didática das teorias da linguagem - em especial, daquelas que se ocupam da língua em emprego, como a perspectiva enunciativa benvenistiana - para o ensino-aprendizagem de língua e literatura na escola.

A ausência de mais oportunidades de produção textual foi notada por alguns estudantes em seus feedbacks (os excertos a seguir estão transcritos exatamente como foram redigidos e, portanto, sem correções linguísticas): "Bom eu queria dizer que eu gostei, mas teve uma parte que eu não gostei porque a gente sempre lia e foi bem poucas vezes que a gente escreveu".

Ainda assim, as duas tarefas de escrita geraram efeitos produtivos na relação dos alunos com a língua. Os instrumentos utilizados para avaliar a produção inicial possibilitaram-lhes ocupar dois distintos lugares enunciativos: o de leitores de seus próprios textos (via grade autoavaliativa) e o de sujeitos-autores (via bilhete orientador de reescrita). Já a socialização das produções finais, embora de apenas três delas, permitiu-lhes conceber seus textos como mais do que "trabalhos" feitos para serem avaliados e receberem uma nota: permitiu-lhes concebê-los como discursos autênticos, com interlocutores reconhecíveis e propósitos significativos.

Dos inúmeros aspectos envolvidos na realização da SD, destacam-se o replanejamento das tarefas de leitura e o redimensionamento do eixo 
temático derivados das situações de preconceito explícito entre os estudantes, por mim testemunhadas ainda no início das aulas. A inserção do debate acerca de culturas historicamente negadas e silenciadas no currículo escolar, a partir da leitura de textos diversos - contos, notícias, infográficos produziu duas contribuições relevantes à formação dos alunos:

a) uma contribuição à sua formação como leitores mais críticos e fruidores, conforme depoimentos de alunas no feedback sobre o projeto - "[...] serviu para ajudar nos textos. Para entender melhor"; "Você me ensinou que a literatura é mais importante do simplesmente ler um livro ou uma histó,

é entender e imaginar usar sua imaginação";

b) uma contribuição à sua formação como cidadãos mais solidários e humanizados, conforme também depoimento de aluna "[...] falamos sobre preconceito, (algo muito presente na sociedade), que de alguma forma faz parte do nosso dia-a-dia".

Os excertos acima revelam indícios de mudanças identitárias por parte dos alunos, enquanto leitores e enquanto cidadãos, mudanças estas mediadas pela linguagem na aula de LPL. A problematização de temas como o racismo, o machismo e a homofobia reforça a importância de explorar os letramentos críticos e protagonistas (ROJO, 2014) na educação, em geral, e na educação linguística, em particular, em prol de uma escola verdadeiramente democrática e cidadã.

Tais letramentos privilegiam o tratamento ético dos discursos em sala de aula, por meio de um exame crítico, contextualizado e capaz de localizar o texto em sua situação de produção e compreensão mais restrita (considerando interlocutores, propósitos e esferas sociais de circulação do gênero textual) e em sua situação sócio-histórica mais ampla (avaliando temas, culturas e ideologias que permeiam as práticas discursivas), o que possibilita a formação do aluno para o exercício da cidadania e o respeito às diferenças.

Segundo Benveniste, ao se apropriar da língua para atualizá-la em discurso na enunciação, "o homem se situa e se inclui em relação à sociedade". Trata-se "[d]a inclusão do falante em seu discurso, [d]a consideração pragmática que coloca a pessoa na sociedade enquanto participante" (BENVENISTE, 1968/2006, p. 101).

Nesse sentido, a aula de Língua Portuguesa e Literatura é um espaço-tempo enunciativo privilegiado para a constituição do aluno não apenas como sujeito de linguagem, capaz de transitar sem dificuldades pelos múltiplos usos da língua, mas também como participante da sociedade, como cidadão ético e sensível à diversidade que colore o mundo.

\section{Referências}

BENVENISTE, É. Da subjetividade na linguagem (1958). In: BENVENISTE, Émile. Problemas de Linguística Geral I. 5.ed. Campinas, SP: Pontes Editores, 2005.

BENVENISTE, É. Vista d'olhos sobre o desenvolvimento da linguística (1963). In: BENVENISTE, Émile. Problemas de Linguística Geral I. 2ed. Campinas, SP: Pontes Editores, 2005.

BENVENISTE, É. Estrutura da língua e estrutura da sociedade (1968). In: BENVENISTE, É. Problemas de Linguística Geral II. 2ed. Campinas, SP: Pontes Editores, 2006.

BENVENISTE, É. O aparelho formal da enunciação (1970). In: BENVENISTE, Émile. Problemas de Linguística Geral II. 2ed. Campinas, SP: Pontes Editores, 2006.

CORAZZA, S. M. Planejamento de ensino como estratégia de política cultural. In: MOREIRA, A. F. (org.). Currículo: questões atuais. 5ed. Campinas: Papirus, 1997.

DOLZ et al. Seqüências didáticas para o oral e a escrita: apresentação de um procedimento. In: SCHNEWLY, B.; DOLZ J. Gêneros orais e escritos na escola. Campinas: Mercado de Letras, 2004, p. 95-128.

KNACK, C.; OLIVEIRA, G. F. Avaliação de textos acadêmicos escritos: uma perspectiva enunciativa. Desenredo, v. 13, n. 03, p. 706-732, set.-dez., 2017. 
KÖCHE, V. S.; BOFF, O. M; MARINELLO, A F. Estudo e produção de textos: gêneros textuais do relatar, narrar e descrever. Petrópolis: Vozes, 2012.

OLIVEIRA, G. F. 'Então eu posso dizer 'eu' na redação? Da subjetividade na linguagem à autoria na argumentação escrita". EID\&A - Revista Eletrônica de Estudos Integrados em Discurso e Argumentação, Ilhéus, n. 13, p. 36-50, jan.-jun., 2017.

OLIVEIRA, G. F. Uma semântica do homem que fala, ouve, escreve e lê em sala de aula: a enunciação benvenistiana e o ensino de língua materna no Brasil. PERcursos Linguísticos, Vitória, v. 8, n. 18, p. 92-192, 2018.

ROJO, R. Letramentos múltiplos, escola e inclusão social. São Paulo: Parábola Editorial, 2014.

ROWLING, J. K. O Conto dos Três Irmãos. In: ROWLING, J. K. Os Contos de Beedle, o Bardo. Rio de Janeiro: Rocco, 2008, p. 85-104.

SANTOMÉ, J. T. As culturas negadas e silenciadas no currículo. In: SILVA, Tomas Tadeu. (Org.). Alienígenas na sala de aula: Uma introdução aos Estudos Culturais da Educação. Rio de Janeiro: Vozes, 1995.

SAVIOLI, Francisco Platão; FIORIN, José Luiz. Lições de texto: leitura e redação. 5.ed. São Paulo: Ática, 2006.

SILVA, T. T. Currículo: uma questão de saber, poder e identidade. In: SILVA, T. T. Documentos de identidade: uma introdução às teorias do currículo. Belo Horizonte: Autêntica, 2001.

SILVA, C. L. da C. Discurso: lugar de constituição da memória e da identidade? In: AQUINO, I. C.; CRESTANI, L. M.; DIAS, L. F. F.; DIEDRICH, M. S. Língua, literatura, cultura e identidade: entrelaçando conceitos. Passo Fundo: Editora Universidade de Passo Fundo, 2016, p. 25-33.

SIMÕES, L. J. et al. Leitura e autoria: planejamento em Língua Portuguesa e Literatura. Erechim: Edelbra; 2012.

SIMÕES, L. J.; FARIAS, B. S. Conversa vai, escrita vem. Almanaque na Ponta do Lápis. São Paulo, CENPEC, no 21, 2013, p. 30-39.

\section{COMO CITAR ESSE ARTIGO}

OLIVEIRA, Giovane Fernandes. Enunciação e cidadania: o replanejamento didático na busca pelas culturas negadas e silenciadas em sala de aula. Signo, Santa Cruz do Sul, v. 44, n. 80, p. 98-121, jul. 2019. ISSN 19822014. Disponível em: <https://online.unisc.br/seer/index.php/signo/article/view/13305>. Acesso em:_ doi: https://doi.org/10.17058/signo.v44i80.13305. 